\title{
Nuclear genome size and karyotype analysis in Papaver for BAC library construction
}

\author{
T. K. Kyrylenko, O. I. Martynenko, O. G. Alkhimova \\ Institute of Molecular Biology and Genetics, National Academy of Sciences of Ukraine \\ 150 Zabolotnoho str., 03143 Kyiv, Ukraine \\ E. mail: alkhimiv@hotmail.com
}

The objective of the research carried out is study of the pathway of alkaloid production in Papaver species and cell lines, and integration data on physical mapping of newly developed marker DNA sequences with existing difference in expression of genes for key enzymes of alkaloid biosynthesis. This research requires the knowledge on genome structure and organization, and development of genomic resources for detailed characterization of opium poppy genome. The work is focused on the investigation of some features of genome organization of Papaver somniferum and related species, Papaver bracteatum and Papaver rhoeas. These characteristics are necessary for the construction of a BAC library which would be used as appropriate genomic resource for characterization of karyotype changes in poppy stocks with altered alkaloid biosynthesis pathway. Some of these stocks (cell lines) were generated and differed in the types of alkaloids they accumulated.

Key words: Papaver, alkaloids, genome size, bacterial artificial chromosome library, FISH.

Introduction. The data from several different alkaloid-producing plants suggest that their biosynthesis and accumulation involve a highly regulated process that includes cell-, tissue-, development and environment-specific controls $[1,2]$. The evolution of alkaloid pathways together with their cellular compartmentation appears to be closely associated with the primary reactions from which they have evolved. Opium poppy, Papaver somniferum, is cultivated for its alkaloid-rich latex. Tyrosine decarboxylase (TyDC) is the first enzyme in poppy alkaloid biosynthesis and is encoded by a small gene family. Members of this family are differentially expressed in organs of the plant and cultivated cells [3]. With the availability of an increasing number of genes involved in alkaloid biosynthesis, increasing efforts would be made to identify the regulators [4] associated with the development of specialized cell types which relate to alkaloid biosynthesis and accumulation. Gene loca(c) ${ }_{2005}$ K. KYRYLENKO, o. I. MARTYNENKO, O. G. ALKHIMOVA. lization and isolation require a detailed knowledge of genome structure. While genetic maps provide information on relative order of molecular markers and genes along the chromosomes, physical mapping provides data on the physical position of DNA sequence within a genome. $P$. somniferum, $P$. bracteatum and $P$. rhoeas belong to one taxonomic section within genus Papaver and produce morphinan and benthophenanthridine type alkaloids which belong to different biosynthetic pathways.

Large-insert DNA libraries are one of the key resources that facilitate gene isolation by positional cloning and the analysis of genome organization, structure and evolution. The easy handling and propagation of the clones make BACs (bacterial artificial chromosomes) an invaluable tool in genomic research, used for a variety of applications, including physical mapping and genome sequencing [5]. The production of full-length cDNA molecules from genomic DNA libraries, representing genes of interest, is of paramount importance in basic plant biology re- 
search as well as plant biotechnology [6]. Estimation of genome size, karyotype parameters, testing restriction endonucleases patterns are the necessary characteristics for BAC library construction.

This study was undertaken to determine nuclear genome size and genomic distribution of ribosomal DNA loci and two families of repetitive DNA sequences in Papaver species representing one taxonomic section within genus Papaver, with the aim to expand the number of species where these characteristics are known, and aid in the construction of a BAC library wich would be used as appropriate genomic resource for characterization of karyotype changes in poppy stocks with altered alkaloid biosynthesis pathway.

Material and Methods. Plant material. For DNA extraction and chromosome slide preparations we used seedlings and roots of poppy species, $P$. somniferum, $P$. bracteatum and $P$. rhoeas (accessions from Kyiv Central Botanic Garden collection). DNA was extracted from etiolated seedlings following $\mathrm{Au}-$ subel et al. [7].

Determination of genome size. According to Dolezel et al. [8 ], approximately $50 \mathrm{mg}$ of midrib was cut from a poppy, $P$. somniferum, young leaf and transferred to a glass Petri dish. About $10 \mathrm{mg}$ of a young leaf of maize (Zea mays cv. CE-777) with $2 \mathrm{C}=$ $=5.43 \mathrm{pg}$ DNA was added and served as an internal reference standard. The tissues were chopped simultaneously in $1 \mathrm{ml}$ of Otto I buffer $(0.1 \mathrm{M}$ citric acid, $0.5 \% \mathrm{v} / \mathrm{v}$ Tween 20). Crude suspension of isolated nuclei was filtered through a $50 \mu \mathrm{m}$ nylon mesh. Nuclei were then pelleted $(300 \mathrm{~g}, 5 \mathrm{~min})$, resuspended in $200 \mu \mathrm{l}$ Otto $\mathrm{I}$ and incubated for $1 \mathrm{~h}$ at room temperature. Finally, $600 \mu \mathrm{l}$ Otto II buffer $(0.4 \mathrm{M}$ $\mathrm{Na}_{2} \mathrm{HPO}_{4}$ ), supplemented with $50 \mu \mathrm{g} / \mathrm{ml}$ RNAse and $50 \mu \mathrm{g} / \mathrm{ml}$ propidium iodide (PI), was added. Samples were analysed using Partec PAS flow cytometer («Partec GmbH», «Munster», Germany) equipped with 488-nm argon laser. The gain of the instrument was adjusted so that peak representing maize G1 nuclei appeared approximately on channel 100 on histogram of relative fluorescence intensity when using 512-channel scale. About 5,000 nuclei were analysed at rate $10-25$ nuclei/s. Three plants were measured per accession. Analysis of each plant was repeated three times on different days. Nuclear DNA content was calculated from individual measurements.

Fluorescence in situ hybridization (FISH). FISH probe for ribosomal DNA was obtained by labelling a pTa71 DNA clone containing $18 \mathrm{~S}, 5.8 \mathrm{~S}$ and $26 \mathrm{~S}$
rRNA genes [9] with biotin-16-dUTP («Roche», Germany) by Nick Translation. Along with rDNA probe two new clones were used. These were made by sonicating total genomic DNA from $P$. somniferum (Danish flag accession) to an average length of 200 to $600 \mathrm{bp}$. The fragments were denatured at $100{ }^{\circ} \mathrm{C}$ in $0.1 \mathrm{M}$ sodium phosphate buffer, $\mathrm{pH} 7.5$, for $10 \mathrm{~min}$ and incubated at $60{ }^{\circ} \mathrm{C}$ to $\mathrm{C}_{0} \mathrm{t}$ of 0.02 . The samples were treated with $\mathrm{S} 1$ nuclease. The resulting highly repeated double-stranded DNA sequences were cloned into $p U C 18$ at the Pstl site. From several thousand clones, 200 were chosen randomly for dot hybridization with ${ }^{32} \mathrm{P}$-labelled total DNA from the representatives of four Papaver taxonomic sections (Meconella, Pilosa, MacranthalPapaver, Argemonidium). Two clones, pPs21 and pPs41 gave very strong signals with $P$. somniferum DNA and no visible signals with three other sections members. These clones were selected for further studies on in situ and southern hybridizations. Digoxigenin-labelled probes for these repeats were prepared using PCR with M13 direct and reverse primers and pPs21 and pPs41 clones as a templates.

Metaphase spreads were prepared according to Alkhimova et al. [10]. The slides were treated with $100 \mathrm{mg} / \mathrm{ml} \mathrm{RNAse}$ in a $2 \times \mathrm{SSC}$ solution at $37^{\circ} \mathrm{C}$ for $1 \mathrm{~h}$ in a humid chamber, washed $3 \times 5 \mathrm{~min}$ in $2 \times \mathrm{SSC}$ at room temperature. After two washes in $2 \times$ SSC the slides were treated in $4 \%$ paraformaldehyde for $10 \mathrm{~min}$ at room temperature, washed in $2 \times \mathrm{SSC}$, dehydrated in ethanol series, and air dried. Prior to hybridization, the probes were mixed in a solution containing $50 \%$ formamide, $10 \%$ dextran sulphate, $0.12 \%$ SDS in $2 \times \mathrm{SSC}$ and $50 \mathrm{ng} / \mu 1$ salmon sperm DNA. $1 \mu \mathrm{l}$ of probe in $30 \mu \mathrm{l}$ hybridization mixture per slide was used. The hybridization mixture was denatured at $70{ }^{\circ} \mathrm{C}$ for $10 \mathrm{~min}$ and incubated on ice for 10-15 min before being added to the preparations. The chromosomes together with the probes were denatured at $70{ }^{\circ} \mathrm{C}$ for $5 \mathrm{~min}$ and the hybridization was performed overnight at $37^{\circ} \mathrm{C}$ in a humid chamber. The slides were then washed in $2 \times$ SSC at $42{ }^{\circ} \mathrm{C}$ and rinsed in a stringent washing solution of $20 \%$ formamide in $0.1 \times \mathrm{SSC}$ at $42{ }^{\circ} \mathrm{C}$ for $10 \mathrm{~min}$, followed by several washes in $2 \times$ SSC and $4 \times$ SSC $(0.2 \%$ Tween). The sites of digoxigenin- and biotin-labelled probe hybridization were detected using anti-digoxigenin fluorescein («Roche») and streptavidin conjugated to Cy3 («Sigma», USA), respectively. Finally, the preparations were counterstained with DAPI $(0.2$ 


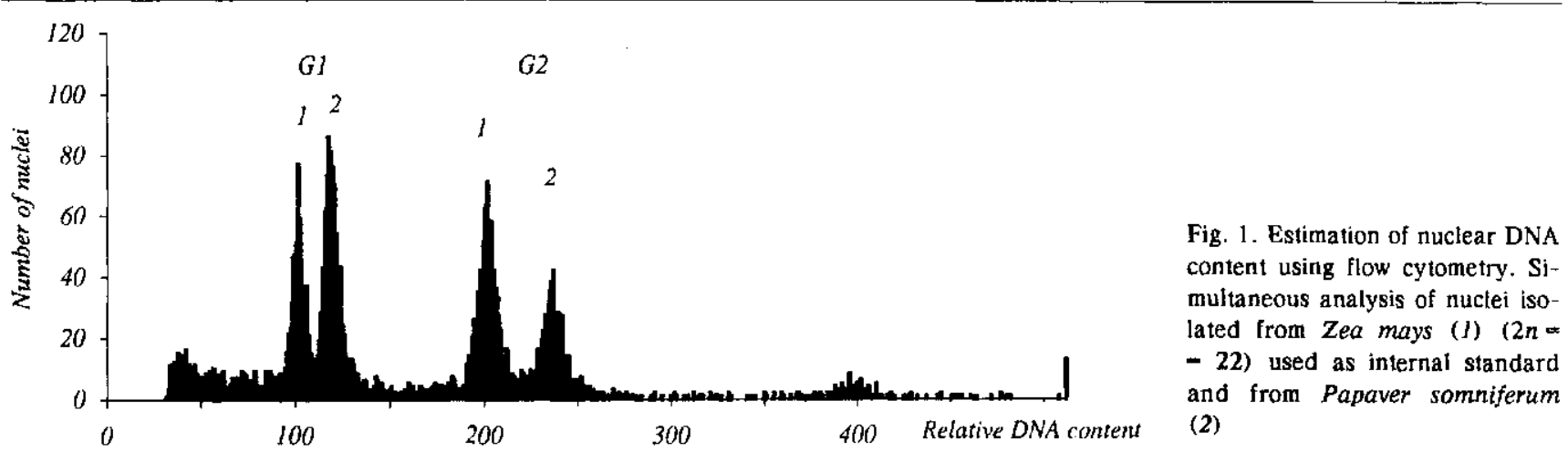

$\mu \mathrm{g} / \mathrm{ml})$ and mounted in Vectashield antifade solution ( Vector Laboratories», USA).

The preparations were evaluated using Olympus BX60 microscope equipped with optical filter sets appropriate for DAPI, fluorescein and $\mathrm{Cy} 3$ fluorescence. The images of DAPI, fluorescein and $\mathrm{Cy} 3$ fluorescence were acquired separately with $a b / w$ CCD camera, which was interfaced to a $P C$ running the ISIS software («Metasystems», «Altlussheim», Germany). The images were superimposed after contrast and background optimization.

Results and Discussion. Estimation of genome size of Papaver somniferum. Flow cytometry is a rapid technique that allows accurate estimation of nuclear DNA content [11]. To determine nuclear DNA content in absolute units, fluorescence intensity of nuclei is compared with that of nuclei isolated from a species with known nuclear genome size. Fluorescence of PI-stained nuclei were analysed using a Partec PAS II flow cytometer. Nuclei isolated from $Z$. mays cv. $\mathrm{CE}-777$ with known nuclear genome size $(2 \mathrm{C}=$ $=5.43 \mathrm{pg}$ DNA) were used as internal standard to estimate nuclear DNA content of $P$. somniferum in absolute units. Small amounts of leaf tissues (standard and sample) were simultaneously chopped in buffer, supplemented with PI and RNAse. Suspension of nuclei was filtered through $50 \mu \mathrm{m}$ nylon and stored on ice prior to analysis. 2C DNA content of $P$. somniferum was calculated according to formula:

$$
\begin{gathered}
2 \mathrm{C} \text { nuclear DNA content }= \\
=\frac{5.43 \times \mathrm{G}_{1} \text { peak mean of Papaver }}{\mathrm{G}_{1} \text { peak mean of } \mathrm{Zea}}=6.46 \mathrm{pg} .
\end{gathered}
$$

Genome size, which represent one copy of nuclear DNA equal to $1 \mathrm{C}$, was further determined as:

Genome size $=$

$=\frac{2 \mathrm{C} \text { nuclear DNA content }(\mathrm{pg})}{2} \cdot 0.978 \cdot 10^{9} \mathrm{bp}[11]$.
The results of the study showed (Fig. 1) that the size of $P$. somniferum nuclear genome equal $6.46 \mathrm{pg}$ is smaller than previously estimated [12].

Karyotype of $P$. somniferum and related species, $P$. bracteatum and $P$. rhoeas. A karyotype, which is characterized by the number and morphology of chromosomes, is an important characteristic of a species. Methods for chromosome preparation and in situ hybridization essentially followed Heslop-Harrison et al. [13]. Root tips were fixed, partially digested with enzymes and cells were spread on slides. At least ten well-spread metaphase plates with similar degree of chromatin condensation were used to make chromosomal measurements. For constructing the karyotype, the chromosomes were arranged in order of decreasing size and increasing asymmetry (Fig. 2).

Localization of $r D N A$ loci and repetitive DNA clones. Fluorescence in situ hybridization on $P$. somniferum chromosomes showed that pPs21 and pPs41 DNA sequences were distributed mostly uniformly along all chromosomes with gaps near centromeres and nucleolar organizer regions (data not shown). FISH with $P$. bracteatum, the representative of the same taxonomic group Macranthal Papaver, is shown in Fig. 3. DNA sequences have been shown to be dispersed over the $P$. bracteatum genome. It had substantially more copies of pPs41 dispersed along most chromosomes (Fig. 3,b) than pPs21 which gave less number of dots.

Preparation of BAC library construction. BAC library is a source of DNA clones, which will be used as landmarks for chromosome identification, and also for the search of clones consisted of single copy sequences. An important step toward the structural analysis of a functional DNA domains is the construction of a large-insert libraries. Their inserts represent large DNA fragments that can be easily localized on mitotic chromosomes using FISH and allow selec- 

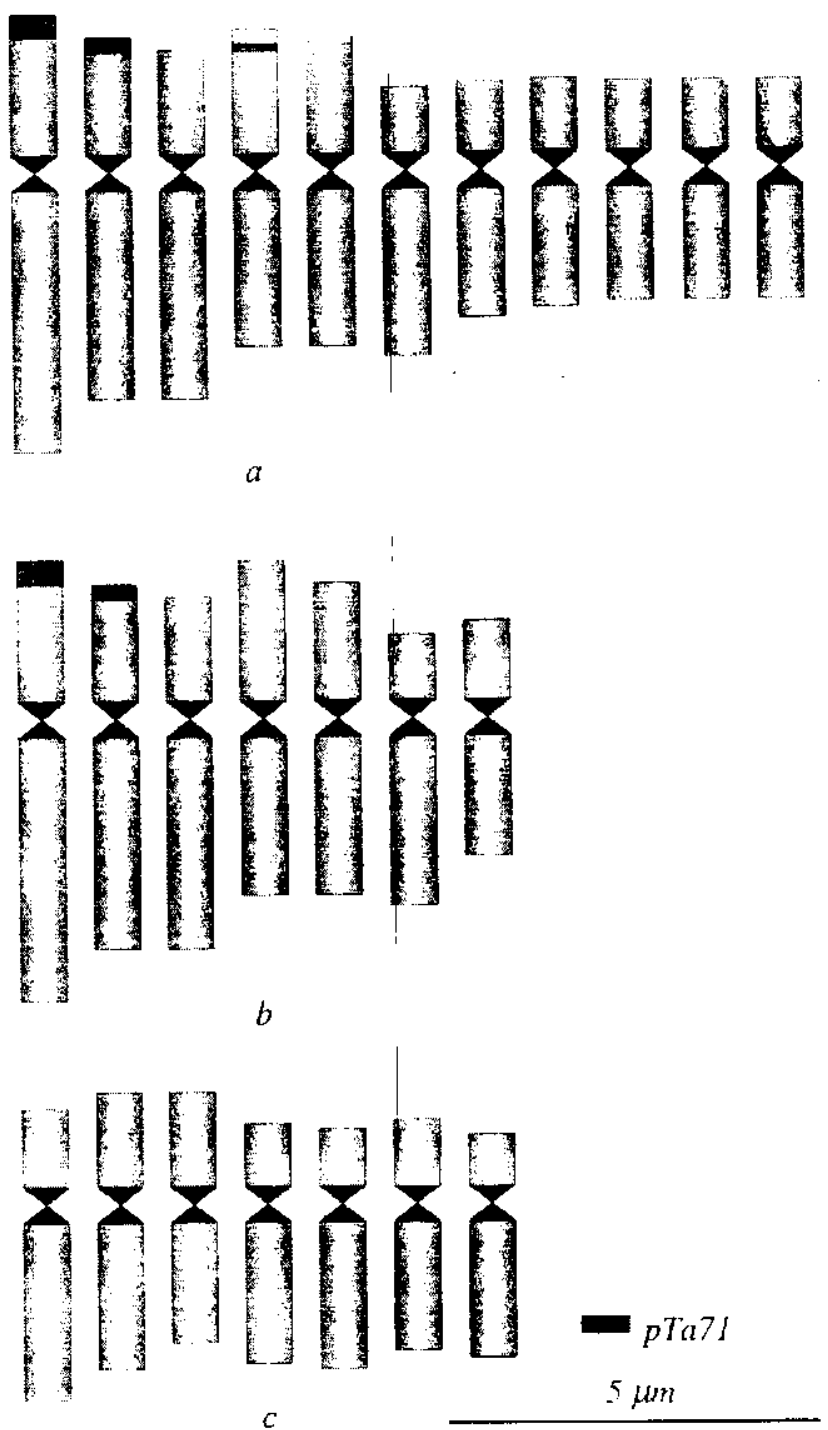

Fig. 2. Karyoidiogram of Pupaver somniferum (a), P. bracteatum (b) and $P$. rhoeas (c) showing the length of individual chromosomes and centromere position. Distribution of rDNA loci revealed by in situ hybridization with pTa71 probe

tion of $\mathrm{BAC}$ clones with deficiency in repetitive DNA sequences. This approach requires determination of restriction endonucleases suitable for library construction, vector selection, appropriate ratio of high molecular weight DNA and chosen vector, optimal ligation and transformation conditions.

Testing conditions for different restriction enzymes. EcoRI, BamHI, or HindIII, the restriction enzymes most frequently used in BAC cloning [5]. High molecular weight DNA of $P$. somniferum, obtained by purification of protoplasts from the seedlings in enzyme solution followed by embedding on lowmelting-point agarose, was digested with the five restriction enzymes, which can be ranged according to
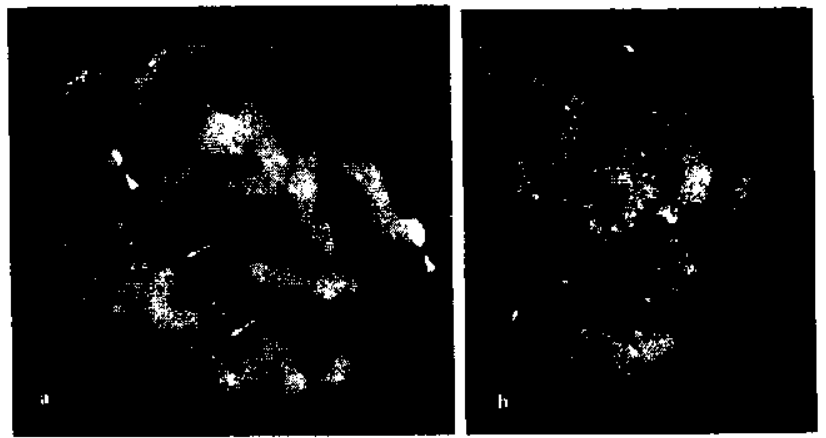

Fig. 3. In situ hybridization showing the localization of repetitive sequences, pPs21 $(a)$ and pPs41 $(b)$, derived from opium poppy, on chromosomes of Papaver bracteatum. Arrows mark NORs, arrowheads indicate major pPs2l sites at the terminal region of two chromosomes

increase of recognition sites, in the next order: $K p n I$, $X$ baI, BamHI, EcoRI, HindIII. As HindIII restriction fragments contained TyDC sequence (hybridization data not shown), and HindIII digestion gave more fragments, this enzyme is chosen for the construction of $P$. somniferum BAC library.

Logistics. The pIndigo BAC-5 (Hindlll-Cloning Ready) vector has been chosen for the $P$. somniferum BAC library construction. The vector is provided in a «ready-to-use» statc. It has been linearized at the unique restriction enzyme recognition site (HindIII), dephosphorylated and rigorously tested for purity and recombinant cloning efficiency (Epicentre). Competent Escherichia coli DH10B cells («Gibco BRL», USA) and Gibco BRL Cell-Porator System («Life Technologies», USA) have been used to get effective and reliable result. The vector to DNA ratio has been calculated to be in proportion approximately 1:10.

Conclusions drawn. The cultured cell lines which accumulated alkaloids of only onc type, morphinan (thebaine) or benthophenanthridine (sanguinarine) have been generated from $P$. bracteatum (Fig. 4). As the members of the TyDC gene family are differentially expressed in cells and organs accumulating predominant alkaloid type [1], one can assume that different genes of this family are «responsible» for the alkaloid type produced. Southern hybridization with TyDC probe have revealed the different organization of restriction fragments in unorganized callus culture $[3,14 \mid$. The opium poppy TyDC gene family is composed of about 15 members that are divided into two subfamilies with regard to the sequence identity [3]. These two groups distinguish in organ-specific expression, namely, the members of the TyDCl-like subgroup are expressed abundantly in roots, while the members of the TyDC2-like subgroup - in roots and 


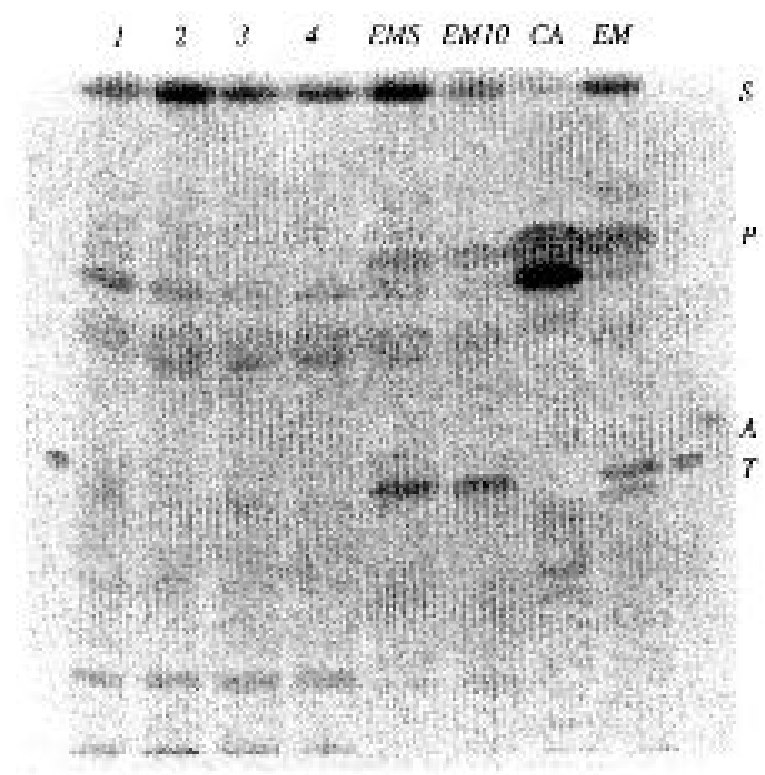

Fig. 4. Thin-layer chromatographic analysis of alkaloids in Papaver bracteatum cultured cell clones: $1-4-$ primary cell cultures (up to 5 months in culture); EM, EM5, EM10 - morphogenous lines; $C A$ - dedifferentiated callus. Authentic standards of sanguinarine $(S)$, protopine $(P)$, allocryptopine $(A)$ and thebaine $(F)$ were also run

stems. The members of the $P$. somniferum TyDC gene family show also differences in the developmental, tissue-specific, and inducible expression patterns. This gene family can be used as a molecular marker to study the regulation and localization of alkaloid biosynthesis in the poppy species.

Fluorescence in situ hybridization has been performed to investigate the physical distribution of repetitive clones along the chromosomes of $P$. somniferum and $P$. bracteatum species. Two new clones have been used, pPs21 and pPs41. In situ hybridization on $P$. somniferum chromosomes has shown that pPs21 and pPs41 DNA sequences are distributed mostly uniformly along all chromosomes with gaps near centromeres and nucleolar organizer regions (data not shown). These repetitive sequences have been shown to be dispersed over the $P$. bracteatum genome distinguishing by the copy numbers of their repeats (Fig. 3). For the first time, the localization of the ribosomal DNA on $P$. bracteatum chromosomes is shown.

BAC library is a source of new DNA clones, which will be used as landmarks for the chromosome identification, and also for searching the clones consisted of single copy sequences. An important step toward the structural analysis of functional DNA domains is the construction of large-insert libraries.
The construction of the representative BAC library requires the determination of the genome size to obtain the appropriate amount of clones. The results of the study show that the size of the $P$. somniferum nuclear genome equal to $6.46 \mathrm{pg}$ is smaller than previously estimated. The genome size of $P$. somniferum $(2 n=22)$ which represents one copy of nuclear DNA equal to $1 \mathrm{C}$, has been determined as $3100 \mathrm{Mb}$. Based on this haploid genome size and average insert size of fragments around $150 \mathrm{~kb}$ that can be cloned efficiently in the BAC vector [5], the library representing five genome equivalents would consist of 100000 clones. Using cDNA probes will allow the verification of the coverage. The results obtained will be used for the construction of the large insert size genomic library as a new molecular resource.

Acknowledgements. We are grateful to Dr J. Dolezel (Institute of Experimental Botany, Olomouc, Czech Republic) for providing us with technical facilities, and P. Suchankova for technical assistance.

This work was supported by the National Academy of Sciences of Ukraine and the International Atomic Energy Agency (Research Contract No. 12235/RBF).

\section{T. К. Кириленко, О. I. Мартиненко, О. Г. Алхімова}

Визначення розміру ядерного геному i каріотипічний аналіз видів Papaver для створення ВАС бібліотеки

Резюме

Роботу присвячено вивченню иляхів біосинтезу алкалоїдів у видів Papaver та інтегруванню даних фізичного картування нових маркерних послідовностей ДНК з відмінностями в експресії генів ключових ферментів біосинтезу алкалоїдів. Таке дослідження потребує знання структури геному та його організацї, а також передбачас наявність геномних ресурсіз задля детального аналізу сеному опійного маку. у даному повідомленні өизначено размір геному опійного маку та зроблено каріотипічний аналіз Papaver somniferum $i$ його сnоріднених видів, P. bracteatum i P. rhoeas. Отримані характеристи$\kappa и$ с необхідними для створення ВАС бібліотеки, яка слугує базисом для цитосенетичносо картування та пошуку змін каріотипу в лініях маку, що відрізняються за шляхами біосинтезу алкалойдів. Вже одержано декілька клітинних ліній, які накопичують різні типи алкалоїдів.

Ключові слова: Pараvет, алкалоїди, розмір геному, ВАС бібліотека, флуоресцентна гібридизація in situ.

\section{Т. К. Кириленко, Е. И. Мартыненко, Е. Г. Алхимова}

Определение размера ядерного генома и кариотипический анализ видов Papaver для создания ВАС библиотеки

Резюме

Работа посвящена изучению пути биосинтеза алкалоидов у видов Pараvеr и интесрированию данных по физическому кар- 
тированию новых маркерных последовательностей ДНК с разлициями в экспрессии генов ключевых ферментов биосинтеза алкалоидов. Такое исследование нуждается в знании структуро генома и его организации, а также предполагает наличие геномных ресурсов для детального анализа генома опийного мака. В даннок сообиении определен размер генома опийного мака и сделан кариотипический анализ Papaver somniferum $и$ его родственных видов, $P$. bracteatum и $P$. rhoeas. Полученные характеристики необходимы для создания ВАС библиотеки, предоставляющей базис для цитогенетического картирования и поиска изменений кариотипа у линий мака, различаюицися путями биосинтеза алкалоидоя. Уже выделень несколько клеточных линий, накапливающих разные типь алкалоидов.

Ключевые слова: Papaver, алкалоиды, размер генома, ВАC библиотеха, флуоресцентная гибридизация in situ.

\section{REFERENCES}

1. Facchini $P$. J, De Luca $V$. Phloem-specific expression of tyrosine/dopa decarboxylase genes and the biosynthesis of isoquinoline alkaloids in opium poppy // Plant Cell._1995.7.-P. 1811-1821.

2. Bird D. A., Franceschi V. R., Facchini P. J. A tale of three cell types: alkaloid biosynthesis is localized to sieve elements in opium poppy // Plant Cell.-2003.-15.-P. 2626-2635.

3. Facchini P. J., De Luca V. Differential and tissue specific expression of a gene family for tyrosine/dopa decarboxylase in opium poppy // J. Biol. Chem.-1994.-269.-P. 2668426690.

4. De Luca V., St Pierre B. The cell and developmental biology of alkaloid biosynthesis // Trends Plant Sci.-2000.-5.-P. $168-173$.

5. Gindullis $F$, Dechyeva D., Schmidt $T$. Construction and characterization of a BAC library for the molecular dissection of a single wild beet centromere and sugar beet (Beta vulgaris) genome analysis // Genome.-2001.-44.-P. 846--855.
6. Moller S. G., Chua N. H. Chemical regulated production of cDNAs from genomic DNA fragments in plants $/ /$ Plant J. $-2002 .-32 .-P .615-622$.

7. Ausubel F. M., Brent R., Kingston R. E., Moore D. D., Seidman J. G., Smith J. A., Struhl K. Current protocols in molecular biology.-New York: Greene/Wiley Int., 1987.$418 \mathrm{p}$.

8. Dolezel J., Greilhuber J., Lucretti S., Meister A., Lysak M., Nardi $L$, Obermayer $R$. Plant genome size estimation by flow cytometry: inter-laboratory comparison // Ann. Bot.-1998.82.-P. 17-26.

9. Gerlach $W$. , Bedbrook $J$. R. Cloning and characterization of ribosomal RNA genes from wheat an barley // Nucl. Acids Res.-1979.-7.-P. 1869-1885.

10. Alkhimova O. G., Heslop-Harrison J. S., Shchapova A. I., Vershinin $A . V$. Rye chromosome variability in wheat-rye addition and substitution lines // Chromosome Res.-1999.7, N 3.-P. 205-212.

11. Dolezel J., Bartos J., Voglmayr H., Greilhuber J. Nuclear DNA content and genome size of trout and human // Cytometry.2003.-51 A.-P. $127-128$.

12. Srivastava S., Lavania U.C. Evolutionary DNA variation in Papaver // Genome.-1991.-34.-P. 763-768.

13. Heslop-Harrison J. S., Schwarzacher $T$., Anamthawat-Jonsson $K$ In situ hybridization with automated chromosome denaturation // Technique.-1991.-3.-P. 109-116.

14. Kyrylenko T. K, Martynenko O. I., Alkhimova O. G. Organspecific expression of tyrosine/dopa genes and the biosynthesis of isoquinoline alkaloids in Papaver sp. $/ / \mathrm{Ukr}$. Biochem. J. - 2002.-74.-P. 35 .

удК 575:577.21.12

Надійшла до редакції 18.12.03 